\section{Vitamin D levels and risk of COVID-19 infection: A systematic review}

\author{
Ana C. Coelho-Oliveira, ${ }^{1,2 \star}$ Bruno B. Monteiro-Oliveira, ${ }^{1,2,3}$ Rebeca B. M. Cavalcante, ${ }^{1}$ Daniel B. Santos, ${ }^{2}$ \\ Anelise Sonza, ${ }^{4}$ Danúbia C. de Sá-Caputo, ${ }^{2,3}$ Mario Bernardo-Filho ${ }^{2}$
}

\begin{abstract}
Objective: Consistent independent associations between low serum 25-hydroxyvitamin D concentrations and susceptibility to acute respiratory tract infections have suggested a possible involvement of vitamin $\mathrm{D}$ in reducing the risk of respiratory infections and proposing its replacement as a potential strategy for prevention or treatment in this context. However, the role of vitamin D supplementation in the infection by the novel coronavirus named SARS-CoV-2 is still under investigation and no clinical evidence has been reported to date. Methods: Electronic searches in Pubmed, Embase and Scopus databases were conducted and three cohort studies that analyzed the effects of interaction of vitamin D with COVID-19, published only in English, were included. Two reviewers, which independently examined titles and abstracts, identified records through database search and reference screening and irrelevant studies were excluded based in eligibility criteria. Relevant full texts were analyzed for eligibility, and all relevant studies were included in the systematic review. Results: Three cohort studies were included in this systematic review with a mean methodological quality low. Only one study demonstrated interaction of low vitamin $D$ concentration in patients with a positive diagnosis for COVID-19. Randomized clinical trials and studies of good methodological quality are necessary to confirm the findings of this systematic review. Conclusions: This systematic review has not demonstrated consistent associations between low levels of vitamin D and susceptibility to COVID-19 infection. Further studies on vitamin D supplementation for the prevention of COVID-19 infection should be conducted..
\end{abstract}

Keywords: Vitamin D; COVID-19; Public health.

\section{Resumo}

Níveis de vitamina $D$ e risco de infecção por COVID-19: Uma revisão sistemática

Objetivo: Associações independentes consistentes entre baixas concentrações séricas de 25-hidroxivitamina D e suscetibilidade a infecções agudas do trato respiratório sugeriram um possível envolvimento da vitamina $\mathrm{D}$ na redução do risco de infecções respiratórias e propuseram sua substituição como uma estratégia potencial para prevenção ou tratamento neste contexto. No entanto, o papel da suplementação de vitamina D na infecção pelo novo coronavírus denominado SARS-CoV-2 ainda está sob investigação e nenhuma evidência clínica foi relatada até o momento. Métodos: Foram realizadas buscas eletrônicas nas bases de dados Pubmed, Embase e Sco-
1. Programa de Pós-Graduação em Fisiopatologia Clínica e Experimental, Instituto de Biologia Roberto Alcântara Gomes. Universidade do Estado do Rio de Janeiro, Rio de Janeiro, RJ, Brazil.

2. Departamento de Biofísica e Biometria, Laboratório de Vibrações Mecânicas e Práticas Integrativas, Instituto de Biologia Roberto Alcantara Gomes. Universidade do Estado do Rio de Janeiro, Rio de Janeiro, Brazil.

3. Faculdade Bezerra de Araújo, Rio de Janeiro, RJ, Brazil.

4. Universidade do Estado de Santa Catarina, Florianópolis, SC, Brazil.

\author{
*Correspondence address: \\ UERJ, PPC, LAVIMP \\ Avenida Marechal Rondon, 381 \\ Rio de Janeiro, RJ, Brasil \\ CEP: 20950-003 \\ E-mail: anacarol_coelho@hotmail.com \\ ORCID https://orcid.org/0000-0002-5491-6060
}

BJHBS, Rio de Janeiro, 2020;19(2):83-90

Received on 03/11/2020. Approved on 10/11/2020.

pus e incluídos três estudos de coorte que analisaram os efeitos da interação da vitamina D com o COVID-19, publicados apenas em inglês. Dois revisores, que examinaram de maneira independente títulos e resumos, identificaram registros por meio de pesquisa de banco de dados e triagem de referência e foram excluídos estudos irrelevantes com base em critérios de elegibilidade. Textos completos relevantes foram analisados para elegibilidade, e todos os estudos relevantes foram incluídos na revisão sistemática. Resultados: Três estudos de coorte foram incluídos nesta revisão sistemática com uma qualidade metodológica média baixa. Apenas um estudo demonstrou interação de baixa concentração de vitamina D em pacientes com diagnóstico positivo para COVID-19. Ensaios clínicos randomizados e estudos de boa qualidade metodológica são necessários para confirmar os achados desta revisão sistemática. Conclusões: Esta revisão sistemática não demonstrou associações consistentes entre baixos níveis de vitamina D e susceptibilidade à infecção por COVID-19. Mais estudos sobre a suplementação de vitamina $D$ para a prevenção da infecção por COVID-19 devem ser realizados..

Descritores: Vitamina D; COVID-19; Saúde pública. 


\section{Original article}

\section{Resumen}

Niveles de vitamina $D$ y riesgo de infección por COVID-19: Una revisión sistemática

Objetivo: Las asociaciones independientes consistentes entre las concentraciones séricas bajas de 25-hidroxivitamina D y la susceptibilidad a las infecciones respiratorias agudas han sugerido una posible participación de la vitamina D en la reducción del riesgo de infecciones respiratorias y proponen su reemplazo como una estrategia potencial de prevención o tratamiento en este contexto. Sin embargo, el papel de la suplementación con vitamina $\mathrm{D}$ en la infección por el nuevo coronavirus llamado SARS-CoV-2 todavía está bajo investigación y hasta la fecha no se ha informado de evidencia clínica. Métodos: Se realizaron búsquedas electrónicas en las bases de datos Pubmed, Embase y Scopus y se incluyeron tres estudios de cohortes que analizaron los efectos de la interacción de la vitamina D con COVID-19, publicados solo en inglés. Dos revisores, que examinaron de forma indepen- diente los títulos y los resúmenes, identificaron los registros mediante la búsqueda en la base de datos y la selección de referencias y se excluyeron los estudios irrelevantes según los criterios de elegibilidad. Se analizaron los textos completos pertinentes para determinar su elegibilidad y todos los estudios relevantes se incluyeron en la revisión sistemática. Resultados: En esta revisión sistemática se incluyeron tres estudios de cohortes con una calidad metodológica media baja. Solo un estudio demostró la interacción de una concentración baja de vitamina $\mathrm{D}$ en pacientes con un diagnóstico positivo de COVID-19. Se necesitan ensayos clínicos aleatorios y estudios de buena calidad metodológica para confirmar los hallazgos de esta revisión sistemática. Conclusiones: Esta revisión sistemática no ha demostrado asociaciones consistentes entre niveles bajos de vitamina $\mathrm{D} y$ susceptibilidad a la infección por COVID-19. Deben realizarse más estudios sobre la suplementación con vitamina $\mathrm{D}$ para la prevención de la infección por COVID-19.

Palabras clave: Vitamina D; COVID-19; Salud pública.

\section{Introduction}

The 2019 coronavirus disease global pandemic (COVID-19), caused by the SARS-CoV-2 coronavirus, has resulted in more than 6 million cases, has caused 376,000 deaths worldwide, and generally produces severe lower respiratory symptoms, according to the World Health Organization (WHO). ${ }^{1}$ However, to this date, there is no specific treatment recommended to help alleviate the symptoms of patients affected with COVID-19 and SARSCOV-2, and some non-pharmacological interventions during the hospitalization, ${ }^{2}$ the confinement ${ }^{3}$ and postCOVID-19 infection have been suggested. ${ }^{4}$

COVID-19 is more prevalent among AfricanAmericans, ${ }^{5}$ persons living in northern cities in the late winter, ${ }^{6}$ older adults, ${ }^{7}$ nursing home residents, ${ }^{8}$ health care workers, ${ }^{9}$ and populations at increased risk of vitamin D deficiency.

Since COVID-19 can manifest with different intensity of symptoms (from asymptomatic to severe symptoms), recently, some studies have reported consistent independent associations between low serum concentrations of 25-hydroxyvitamin D (the major circulating vitamin D metabolite) and susceptibility to acute respiratory tract infection, ${ }^{10}$ suggesting a possible involvement of vitamin $\mathrm{D}$ in reducing the risk of respiratory tract infections and proposing its replacement as a potential strategy for prevention or treatment,

especially in the context of influenza and COVID-19. However, the role of vitamin D supplementation in the context of virus infection is still under investigation, and no clinical evidence has been reported yet.

Although vitamin D deficiency is common in a large part of the general population, disparities in socioeconomic standards, housing conditions, socialization habits and risk perception, people living in higher latitudes, and especially ethnic conditions, have potential implications for the risk of COVID-19 exposure and transmission, presenting higher rates among people with darker skin or reduced exposure to ultraviolet (UV) radiation from the sun. ${ }^{11,12}$

Authors describe vitamin D hormone as having important functions - including immunomodulant, anti-inflammatory and anti-infective roles..$^{13}$ It acts via monocyte and cell-mediated immunity stimulation, suppression of lymphocyte proliferation, antibody production and cytokine synthesis. ${ }^{10}$ Human lung cells are able to intracellularly convert the inactive $25(\mathrm{OH}) \mathrm{D}$ to its active form $1,25(\mathrm{OH}) \mathrm{D}$, which reduces proinflammatory cytokines and increases peptides (e.g.the innate antimicrobial peptide cathelicidin). Cathelicidin has direct antiviral activity against enveloped respiratory viruses such as hepatitis B, influenza, respiratory syncytial virus and possibly the COVID-19 as well..$^{10}$ Nevertheless, evidence of whether vitamin D deficiency is associated with COVID-19 infection is lacking and/or could help 
establish vitamin D as an evidence-based approach to decrease the burden and potentially the spread of COVID-19. Considering this rationale, the aim of this systematic review is to assess the effects of the association of vitamin D and COVID-19.

\section{Methods}

The review was based on the Preferred Reporting Items for Systematic Reviews and Meta-Analysis (PRISMA) guidelines ${ }^{14}$ and the methods were prespecified in a protocol that was registered under number CRD42020196135 in the PROSPERO International Prospective Register of Systematic Reviews(PROSPERO). ${ }^{15}$

Search Strategy: It was conducted an electronic search in Pubmed, Embase and Scopus databases in June $22^{\text {th }}$ 2020, using the following search string ("covid 19" OR "covid-19" OR "coronavirus" OR "SARS-Cov-2") AND ("vitamin $\mathrm{D}$ "). The keywords used in the search were defined based on the PICO strategy, focusing on patients with COVID-19 (Participants) and its relationship with vitamin D (Intervention) without restrictions regarding comparisons (Comparison). All reported outcomes (Outcomes) were allowed if considered relevant to the studied population. ${ }^{16}$

\section{Eligibility Criteria}

Inclusion criteria: To be included in this review, the works must be full articles, meet the search criteria and investigate effects of vitamin D on COVID-19 patients, independent of the year of the publication. A flowchart (Figure 1), based in the PRISMA analysis was done to show the steps in the selection of the full papers analyzed in this review. ${ }^{14}$

Exclusion criteria: Exclusion criteria allowed the elimination of unnecessary publications. Papers were excluded if: (i) published in a language other than English; (ii) with findings not related to COVID-19 and vitamin D; (iii) being replies, editorials, letters, abstracts, reviews, commentary's or short communications; and (iv) being conducted with animal, or with combined treatments.

Level of evidence of the selected papers: The level of evidence of each selected publication was individually assessed by using the National Health and Medical Research Council hierarchy of evidence. ${ }^{17}$ The level of evidence was defined as follows: (i) I, the systematic review of level II studies; (ii) II, the randomized clinical trial (RCT); (iii) III-1, the pseudo-randomized controlled trial (alternate allocation, as a crossover study or some other similar method); (iv) III-2, the comparative study with concurrent controls (non-randomized experimental trial, cohort study, case control study, interrupted time series with a control group); (v) III-3, the comparative study without concurrent control (historical control, two or more single arm study, interrupted time series without a parallel control group; and (vi) IV, the case series with either post-test or pretest/ post-test outcomes.

Study Selection and Data Extraction: All references were exported to a data management software (EndNote X9), and duplicates were removed. The review was conducted following four steps. Records were identified through database search and reference screening (Identification), and two reviewers independently examined titles and abstracts and irrelevant studies were excluded based in eligibility criteria (Screening). Relevant full texts were analyzed for eligibility (Eligibility), and all relevant works were included in the systematic review. The disagreement was resolved by a third reviewer. The same researchers were responsible for the data extraction from the included studies. Data regarding study information (author and year), study design, objectives, and outcomes were extracted.

\section{Results}

A total of 277 studies were identified through a database search and, after the removal of 138 duplicates, 139 studies were identified. During the screening process, 127 publications were excluded for not being related to the research question and the full text of 11 articles was reviewed in detail. After careful analysis, 8 studies were excluded (5 review articles, 2 commentaries and 1 vitamin $\mathrm{D}$ and other treatment). Finally, three publications were included in the systematic review. The selection process is summarized in Figure 1.

Table 1 shows the characteristics of the participants, the aims of the studies, the outcomes of the selected articles and the level of evidence of the selected papers. The levels of evidence ${ }^{17}$ for all studies included in the current review were considered LE III -2.

Several outcomes have been assessed in the matter of whether (i) vitamin D reduces the risk of infection, (ii) vitamin D deficiency is associated with COVID-19 infection and (iii) there is a correlation between vitamin D and COVID -19 in black and South Asian people. 
Original article

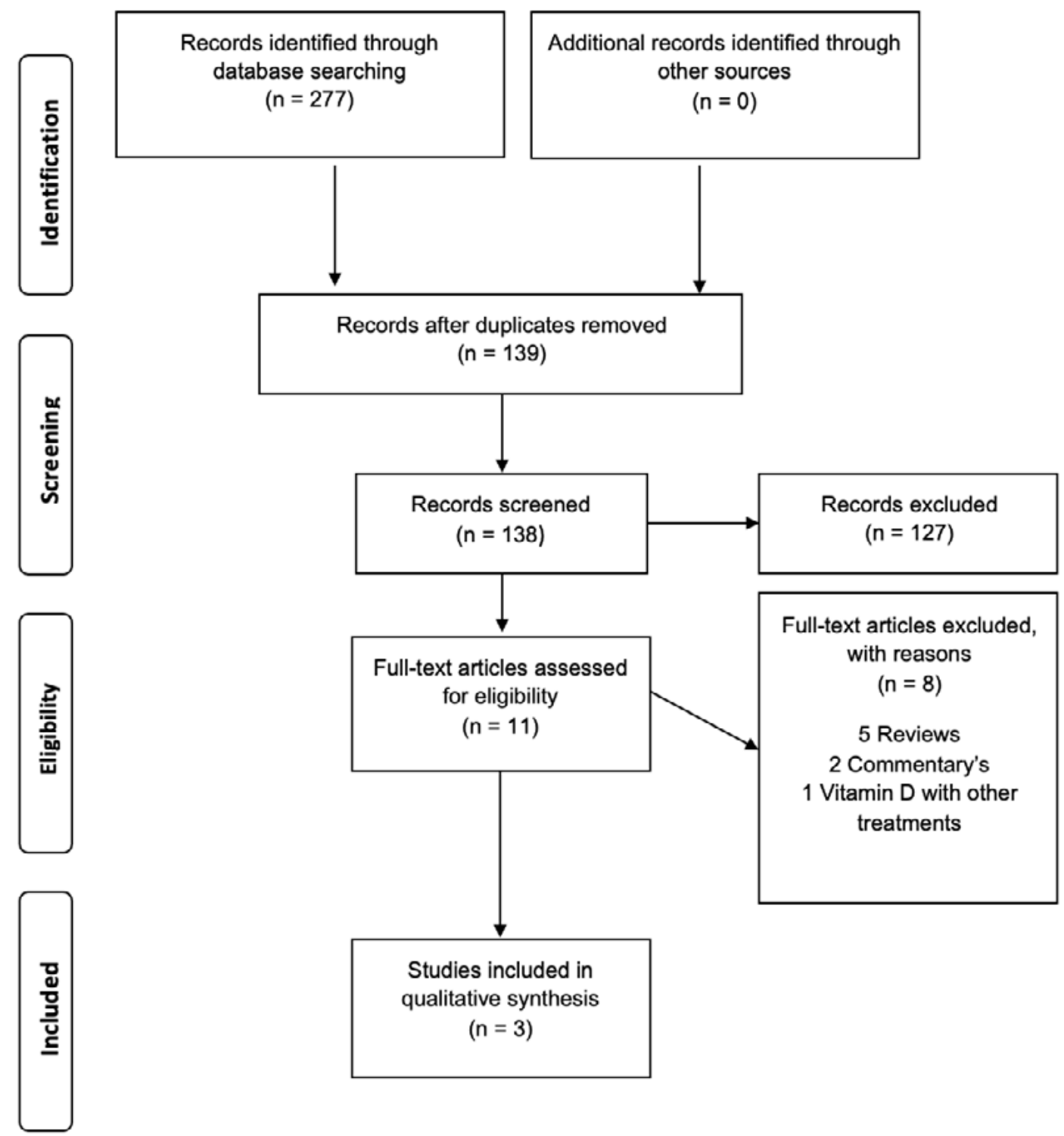

Figure 1. PRISMA flow diagram of the literature selection process

Regarding the main findings based on the results, vitamin D was lower in patients positive for SARSCoV-2 PCR compared to negative patients. ${ }^{18}$

The works used populations of three countries, UK, USA, and Switzerland. The studied population ranged from 107 to 348,598 individuals with an average age ranging from 45.7 to 73 years and the concentration of vitamin D ranged from 22 to $32.7 \mathrm{ng} / \mathrm{mL}$. One work ${ }^{18}$ evaluated two groups: 27 individuals SARS-CoV2 positive (54,2\% males) with median age of 73 years and median vitamin $\mathrm{D}$ of $22 \mathrm{ng} / \mathrm{mL}$ and 80 individuals SARS-Cov2 negative ( $48.8 \%$ males) with median age of 73 years and median vitamin D of $24.6 \mathrm{ng} / \mathrm{mL}$; one work ${ }^{19}$ evaluated 4,314 individuals with median age 
Table 1. Description of the selected studies

\begin{tabular}{|c|c|c|c|c|c|}
\hline Study & Demograph & $\begin{array}{l}\text { Type of } \\
\text { study }\end{array}$ & Objective & Results & $\begin{array}{l}\text { Level of } \\
\text { Evidence }\end{array}$ \\
\hline $\begin{array}{l}\text { D'Avolio et al, } \\
2020\end{array}$ & $\begin{array}{l}\text { Total } 107 \text { patients in } 2 \\
\text { groups. } \\
\text { male = 54.2\%; } \\
\text { median age = } 73 \text { years } \\
25(\mathrm{OH}) \mathrm{D}=22.0 \mathrm{ng} / \mathrm{mL} \text {. } \\
27 \text { SARS-CoV-2 PCR-positive } \\
\text { male = } 70.4 \% \text {; } \\
\text { Median age }=74 \text { years } \\
25(\mathrm{OH}) \mathrm{D}=11.1 \mathrm{ng} / \mathrm{mL} \\
80 \mathrm{SARS}-\mathrm{CoV}-2 \mathrm{PCR}-\mathrm{negative} \\
\text { male }=48.8 \% \text {; } \\
\text { median age }=73 \text { years } \\
\text { median } 25(\mathrm{OH}) \mathrm{D}=24.6 \mathrm{ng} / \\
\mathrm{mL} \\
\text { Switzerland }\end{array}$ & $\begin{array}{l}\text { Cohort } \\
\text { retrospective } \\
\text { study }\end{array}$ & $\begin{array}{l}\text { The involvement } \\
\text { of vitamin } D \text { in } \\
\text { reducing the risk of } \\
\text { infections. }\end{array}$ & $\begin{array}{l}\text { Statistically significant ( } p= \\
0.004) \text { lower } 25(\mathrm{OH}) \mathrm{D} \text { levels } \\
(11.1 \mathrm{ng} / \mathrm{mL} \text { ) in patients po- } \\
\text { sitive for the SARS-CoV-2 PCR } \\
\text { compared with the negative } \\
\text { patients ( } 24.6 \mathrm{ng} / \mathrm{mL} \text { ) was } \\
\text { observed. } \\
\text { When stratifying the } 2020 \\
\text { patients by age ( } 0-70 \text { years } \\
\text { and }>70 \text { years) and PCR } \\
\text { positivity, and considering } \\
\text { only patients with age }>70 \\
\text { years ( } \mathrm{n}=43 \text { vs. } n=18 \text { ), the } \\
\text { vitamin } D \text { concentrations are } \\
\text { significantly different ( } p= \\
0.037), \text { with median values of } \\
23.1 \mathrm{ng} / \mathrm{mL} \text { in PCR-negative } \\
\text { patients vs. } 9.3 \mathrm{ng} / \mathrm{mL} \text { in } \\
\text { PCR-positive patients. }\end{array}$ & III - 2 \\
\hline $\begin{array}{l}\text { D'Meltzer et } \\
\text { al, } 2020\end{array}$ & $\begin{array}{l}\text { Total } 4,314 \text { patients. } \\
\text { male }=35 \% \text {, females }(65 \%) ; \\
\text { median age = } 45.7 \text { years } \\
\text { SARS-CoV-2 positive and } \\
\text { deficiency Vitamin D } \\
32 \text { of } 178(18 \%) \\
\text { SARS-CoV-2 positive and } \\
\text { non-deficient patients } \\
40 \text { of } 321(11 \%) \\
\text { USA }\end{array}$ & $\begin{array}{l}\text { Cohort } \\
\text { retrospective } \\
\text { study }\end{array}$ & $\begin{array}{l}\text { Deficiency analysis } \\
\text { and vitamin D } \\
\text { treatment are } \\
\text { associated with a } \\
\text { positive test for } \\
\text { COVID-19. }\end{array}$ & $\begin{array}{l}\text { The Vitamin D dose was not } \\
\text { significantly associated with } \\
\text { testing positive for COVID-19. }\end{array}$ & III - 2 \\
\hline $\begin{array}{l}\text { Hastie et al, } \\
2020\end{array}$ & $\begin{array}{l}\text { Total 348,598 } \\
\text { SARS-CoV-2 positive } \\
\text { Male } 265(59.02 \%) \\
\text { Female } 184(40.98 \%) \\
\text { Mean Age } 49 \\
25(\mathrm{OH}) \mathrm{D}=28.7 \mathrm{ng} / \mathrm{mL} \\
\text { SARS-CoV-2 negative } \\
\text { Male } 168,391(48.37) \\
\text { Female } 179,758(51.63) \\
\text { Mean Age } 49 \\
25(\mathrm{OH}) \mathrm{D}=32.7 \mathrm{ng} / \mathrm{mL} \\
\text { UK }\end{array}$ & $\begin{array}{l}\text { Cohort } \\
\text { Prospective } \\
\text { study }\end{array}$ & $\begin{array}{l}\text { The objective of the } \\
\text { study was to assess } \\
\text { whether there is an } \\
\text { association between } \\
(25(\mathrm{OH}) \mathrm{D}) \text { and the } \\
\text { risk of COVID-19 } \\
\text { and explaining the } \\
\text { higher incidence of } \\
\text { COVID-19 in black } \\
\text { and South Asian } \\
\text { people }\end{array}$ & $\begin{array}{l}\text { Did not find a potential betwe- } \\
\text { en vitamin D concentrations } \\
\text { and risk of } \\
\text { COVID-19 infection, nor that } \\
\text { vitamin D concentration can } \\
\text { explain ethnic differences } \\
\text { Contagion of COVID-19. }\end{array}$ & III - 2 \\
\hline
\end{tabular}

Legends: 25(OH)D: Vitamin D; UK: United Kindon; USA: United States of America. 


\section{Original article}

of 45.7 years and a greater number of females (65\%) than males (35\%); and one work ${ }^{20}$ evaluated 348,598 individuals in two groups: 449 individuals SARS-CoV2 positive (59.02\% males) with median age of 49 years and median vitamin D of $28.7 \mathrm{ng} / \mathrm{mL}$, and 348.149 individuals SARS-Cov2 negative (48.37\% males) with median age of 49 years and median vitamin D of 32.7 $\mathrm{ng} / \mathrm{mL}$.

\section{Discussion}

The main goal of this systematic review was to assess the effects of the association of vitamin $\mathrm{D}$ and COVID-19. After analyzing the included studies and considering their limitations, it was clear that studies with better quality are lacking, indicating a promising field of study. The methodological quality and level of evidence of the included studies in this review were low, mainly regarding the lack of experimental studies with interventions on this context. So far, only observational studies have been carried out.

The results of the works included in this review are not sufficient to establish the association between the vitamin $\mathrm{D}$ concentration and the predisposition to COVID-19 infection, but this correlation may be possible. Two retrospective studies found this association. D'Avolio et al. ${ }^{18}$ found that individuals with a positive diagnosis of SARS-CoV-2 had lower plasma concentrations of 25-hydroxyvitamin $\mathrm{D}$, compared to individuals with a negative diagnosis. Meltzer et al. ${ }^{19}$ observed that vitamin D deficiency that is not sufficiently treated is associated with COVID-19 risk. In the other hand, Hastie et al., ${ }^{20}$ in a prospective study, did not find this association.

Few reviews consider the mechanisms through which vitamin D reduces the risk of viral infections. ${ }^{21,22}$ It is believed that vitamin $\mathrm{D}$, being a fat-soluble vitamin, is activated in the lung and acts in the modulation of the renin-angiotensin system, decreasing the release of the ECA2 enzyme, which is a gateway to COVID-19 in the lung. ${ }^{23}$ Additionally, Martineau et al. ${ }^{24}$ concluded in a meta-analysis that vitamin D supplementation was safe and protective against acute respiratory tract infections. However, although there are studies suggesting that this supplementation may also be effective for COVID-19, only one article included in this review suggests vitamin $\mathrm{D}$ as a protective factor for this virus.

According to the literature, vitamin D deficiency is highly prevalent around the world, as around $7 \%$ of the world population has severe deficiency and about $40 \%$ live with modest deficiency. ${ }^{25}$ Individuals from colder regions, higher latitudes, and the elderly, who experience little exposure to sunlight, are also more vulnerable to vitamin D deficiency and consequently to more respiratory symptoms, ${ }^{12}$ as well as COVID-19.

Most vitamin D results from production in the skin following exposure to ultraviolet (UV) radiation from the sun; therefore, UV radiation is the main source of vitamin D, providing around $80 \%$ of its production. Individuals with dark skin have, on average, lower concentrations of blood vitamin D because the melanin in dark skin does not absorb as much UV radiation. ${ }^{26}$ These findings corroborate with two studies in this review that suggest an association between deficiency of vitamin $\mathrm{D}$ and the development of COVID-19.

A recent population-based study utilizing data from a large health maintenance organization in Israel that evaluated associations of plasma 25(OH)D status with the likelihood of coronavirus disease infection and hospitalization concluded that low plasma $25(\mathrm{OH})$ $\mathrm{D}$ level appears to be an independent risk factor for COVID-19 infection and hospitalization, after adjusting for age, gender, socioeconomic status (SES) and chronic, mental and physical disorders. ${ }^{27}$ The discrepancy between the results of Hastie et al. ${ }^{20}$ and the findings of the Israeli population study can be explained by a smaller sample size, by the elderly population and by the inability to control various confounding factors in the first study, like SES and chronic medical conditions.

A review article on the plausible mechanisms that link vitamin D deficiency to increased susceptibility to severe COVID-19 infection in patients with diabetes found sufficient evidence of a shared pathophysiological and mechanistic link between diabetes and COVID-19 infection most evident in presence of vitamin D levels below $10 \mathrm{ng} / \mathrm{mL}$, pointing out that health care providers need to ensure adequate level of vitamin D in such situation. ${ }^{28}$

The present systematic review has some limitations and therefore the results should be interpreted with caution. It was not possible to assess the risk of bias, due to the design of the studies included in the review. Only cohort studies were included, the searches were performed only in three databases and in the English language.

The strength of this work is related to the identification of acceptable, relatively safe and inexpensive intervention (i.e., vitamin D) able to 
determine improvements and reducing COVID-19 infection rate.

\section{Conclusion}

Vitamin D deficiency and insufficiency is a worldwide issue and adequate levels of this fat-soluble vitamin are required for the proper functioning of the body's defense system. This systematic review has not demonstrated widely consistent associations between low levels of vitamin D and susceptibility to COVID-19. Further placebo-controlled randomized clinical trials on vitamin D supplementation for the prevention of this infection should be conducted in populations with a high prevalence of vitamin D deficiency, addressing the impact of the replacement regimen and aiming to detect effects in different subgroups. Studies will

\section{References}

1. World Health Organization. Coronavirus disease (COVID-19) Situation Report-134 [Internet]. 2020 [cited 2020 Jul 7]. Available from: https://www.who.int/docs/default-source/ coro\%0D\%0Anaviruse/situation-reports/20200602-covid-19-sitrep-134.pdf \%0D\%0A

2. Sañudo B, Seixas A, Gloeckl R, et al. Potential application of whole body vibration exercise for improving the clinical conditions of covid-19 infected individuals: A narrative review from the world association of vibration exercise experts (wavex) panel. International Journal of Environmental Research and Public Health. 2020.

3. da Cunha de Sá-Caputo D, Taiar R, Seixas A, et al. A Proposal of Physical Performance Tests Adapted as Home Workout Options during the COVID-19 Pandemic. Appl Sci [Internet]. 2020 Jul 10 [cited 2020 Jul 24];10(14):4755. Available from: https:// www.mdpi.com/2076-3417/10/14/4755

4. Li Z, Zheng C, Duan C, et al. Rehabilitation needs of the first cohort of post-acute COVID-19 patients in Hubei, China. Eur J Phys Rehabil Med [Internet]. 2020 Jul [cited 2020 Jul 24];56(3):339-44. Available from: http://www.ncbi.nIm.nih.gov/ pubmed/32672029

5. Garg S, Kim L, Whitaker M, et al. Hospitalization Rates and Characteristics of Patients Hospitalized with Laboratory-Confirmed Coronavirus Disease 2019 - COVID-NET, 14 States, March 1-30, 2020. MMWR Morb Mortal Wkly Rep [Internet]. 2020 Apr 17 [cited 2020 Jul 7];69(15):458-64. Available from: https://www.cdc.gov/mmwr/volumes/69/wr/mm6915e3.htm

6. JC U. Casting Sunlight on an Epidemic [Internet]. MedPage Today. 2020 [cited 2020 Jul 7]. Available from: https://www. medpagetoday.com/infectiousdisease/covid19/85596

7. National Center for Health Statistics. Provisional Death Counts for Coronavirus Disease (COVID-19) [Internet]. U.S. Department of Health and Human Services. 2020 [cited 2020 Jul 7]. Available from: https://www.cdc.gov/nchs/nvss/vsrr/covid19/ index.htm require careful consideration to adapt this treatment to the specific needs of each patient.

\section{Conflicts of interest}

The authors declare that they have no conflicts of interest.

\section{Acknowledgments}

The authors of this study would like to thank Conselho Nacional de Desenvolvimento Científico e Tecnológico (CNPq), Fundação Carlos Chagas filho de Amparo à Pesquisa do Estado do Rio de Janeiro(FAPERJ), and Coordenação de Aperfeiçoamento de Pessoal de Nível Superior (CAPES).

8. Prevention $\mathrm{C}$ for DC and. Preparing for COVID-19 in Nursing Homes [Internet]. 2020 [cited 2020 Jul 7]. Available from: https://www.cdc.gov/coronavirus/2019-ncov/hcp/long-term-care. html

9. Burrer SL, de Perio MA, Hughes MM, et al. Characteristics of health care personnel with Covid-19 - United States, February 12-April 9, 2020. Morb Mortal Wkly Rep [Internet]. $2020 \mathrm{Apr}$ 17 [cited $2020 \mathrm{Jul}$ 7];69(15):477-81. Available from: http:// www.cdc.gov/mmwr/volumes/69/wr/mm6915e6.htm?s_cid=mm6915e6_w

10. Beard JA, Bearden A, Striker R. Vitamin D and the anti-viral state. J Clin Virol [Internet]. 2011 Mar 1 [cited 2020 Jul 7];50(3):194-200. Available from: https://linkinghub.elsevier. com/retrieve/pii/S1386653210004932

11. Martineau AR, Jolliffe DA, Greenberg L, et al. Vitamin D supplementation to prevent acute respiratory infections: individual participant data meta-analysis. Health Technol Assess (Rockv) [Internet]. 2019 Jan 1 [cited 2020 Jul 7];23(2):1-44. Available from: https://pubmed.ncbi.nlm.nih.gov/30675873/

12. Forrest KYZ, Stuhldreher WL. Prevalence and correlates of vitamin D deficiency in US adults. Nutr Res [Internet]. 2011 Jan [cited $2020 \mathrm{Jul}$ 7];31(1):48-54. Available from: https://linkinghub.elsevier.com/retrieve/pii/S0271531710002599

13. Grant WB, Lahore $H$, McDonnell SL, et al. Evidence that vitamin d supplementation could reduce risk of influenza and covid-19 infections and deaths [Internet]. Vol. 12, Nutrients. MDPI AG; 2020 [cited $2020 \mathrm{Jul}$ 7]. p. 988. Available from: https://www. mdpi.com/2072-6643/12/4/988

14. Liberati A, Altman DG, Tetzlaff J, et al. The PRISMA statement for reporting systematic reviews and meta-analyses of studies that evaluate healthcare interventions: explanation and elaboration. BMJ [Internet]. 2009 Dec 4;339(jul21 1):b2700-b2700. Available from: http://www.bmj.com/cgi/doi/10.1136/bmj.b2700

15. Pacheco RL, Latorraca C de OC, Martimbianco ALC, et al. PROSPERO: base de registro de protocolos de revisões sistemáticas. Estudo descritivo. Diagnóstico Trat [Internet] 2018;23(3):101-4. Available from: http://docs.bvsalud.org/ 


\section{Original article}

biblioref/2019/01/969297/rdt_v23n3_101-104.pdf

16. Costantino G, Montano N, Casazza G. When should we change our clinical practice based on the results of a clinical study? The hierarchy of evidence. Intern Emerg Med [Internet]. 2015 Sep 10 [cited 2020 Jul 7];10(6):745-7. Available from: https:// pubmed.ncbi.nlm.nih.gov/25860505/

17. Merlin T, Weston A, Tooher R, Australian Government. NHMRC additional levels of evidence and grades for recommendations for developers of guidelines. BMC Med Res Methodol. 2009;9(34):1-23.

18. D'Avolio A, Avataneo V, Manca A, et al. 25-Hydroxyvitamin D Concentrations Are Lower in Patients with Positive PCR for SARS-CoV-2. Nutrients [Internet]. 2020 May 9;12(5):1359. Available from: https://www.mdpi.com/2072-6643/12/5/1359

19. Meltzer DO, Best TJ, Zhang $\mathrm{H}$, et al. Association of Vitamin D Deficiency and Treatment with COVID-19 Incidence. medrxiv. 2020;

20. Hastie CE, Mackay DF, Ho F, et al. Vitamin D concentrations and COVID-19 infection in UK Biobank. Diabetes Metab Syndr Clin Res Rev [Internet]. 2020 Jul;14(4):561-5. Available from: https://linkinghub.elsevier.com/retrieve/pii/S1871402120301156

21. Greiller $\mathrm{CL}$, Martineau AR. Modulation of the immune response to respiratory viruses by vitamin $D$ [Internet]. Vol. 7, Nutrients. MDPI AG; 2015 [cited 2020 Jul 15]. p. 4240-70. Available from: www.mdpi.com/journal/nutrients

22. Gombart AF, Pierre A, Maggini S. A review of micronutrients and the immune system-working in harmony to reduce the risk of infection. Nutrients [Internet]. 2020 Jan 16 [cited 2020 Jul 15];12(1):236. Available from: https://www.mdpi.com/2072$6643 / 12 / 1 / 236$
23. Malek Mahdavi A. A brief review of interplay between vitamin $\mathrm{D}$ and angiotensin-converting enzyme 2 : Implications for a potential treatment for COVID-19. Rev Med Virol [Internet]. 2020;(April):1-6. Available from: http://www.ncbi.nlm.nih.gov/ pubmed/32584474

24. Martineau AR, Jolliffe DA, Hooper RL, et al. Vitamin D supplementation to prevent acute respiratory tract infections: systematic review and meta-analysis of individual participant data. BMJ [Internet]. 2017 Feb 15 [cited 2020 Jul 15];356:i6583. Available from: http://dx.doi.org/10.1136/bmj.i6583

25. Bouillon R. Vitamin D status in Africa is worse than in other continents. Lancet Glob Heal [Internet]. 2020 Jan 1 [cited 2020 Jul 15];8(1):e20-1. Available from: https://linkinghub.elsevier. com/retrieve/pii/S2214109X19304929

26. Nair R, Maseeh A. Vitamin D: The sunshine vitamin [Internet]. Vol. 3, Journal of Pharmacology and Pharmacotherapeutics. Wolters Kluwer -- Medknow Publications; 2012 [cited 2020 Jul 15]. p. 118-26. Available from: /pmc/articles/PMC3356951/?report=abstract

27. Merzon E, Tworowski D, Gorohovski A, et al. Low plasma $25(\mathrm{OH})$ vitamin D3 level is associated with increased risk of COVID-19 infection: an Israeli population-based study. medRxiv [Internet]. 2020 Jan 1;2020.07.01.20144329. Available from: http://medrxiv.org/content/early/2020/07/03/2020.07.01.20144329.abstract

28. Singh SK, Jain R, Singh S. Vitamin D deficiency in patients with diabetes and COVID- 19 infection. Diabetes Metab Syndr Clin Res Rev [Internet]. 2020 Sep 3 [cited 2020 Jul 15];14(5):1033-5. Available from: http://www.ncbi.nlm.nih.gov/ pubmed/32640414 